\title{
BEECH FORESTS AS WORLD HERITAGE IN ASPECT TO THE NEXT EXTENSION OF THE ANCIENT AND PRIMEVAL BEECH FORESTS OF THE CARPATHIANS AND OTHER REGIONS OF EUROPE WORLD HERITAGE SITE
}

\author{
Ivana Jovanović, Aleksandar Dragišić, Dragana Ostojić, Biljana Krsteski \\ Institute for Nature Conservation of Serbia, Dr Ivana Ribara 91, 11000 Belgrade, Serbia \\ e-mail:ivana.jovanovic@zzps.rs, aleksandar.dragisic@zzps.rs,dragana.ostojic@zzps.rs,biljana.krsteski@zzps.rs
}

\begin{abstract}
Beech forests were first protected under the World Heritage Convention in 2007 as the Primeval Beech Forests of the Carpathians (Slovakia and Ukraine). After two latter extensions in 2011 and 2017, the Natural World Heritage site is currently named the Ancient and Primeval Beech Forests of the Carpathians and Other Regions of Europe (Albania, Austria, Belgium, Bulgaria, Croatia, Germany, Italy, Romania, Slovakia, Slovenia, Spain and Ukraine) and consists of 78 component parts in 12 European countries. It aims to ensure the preservation of beech gene pool, ecosystem and species diversity of beech forests, their future renewal and expansion, in regard to the development and use pressures they encounter and the biodiversity they support. Additionally, this World Heritage site aims to depict the beech expansion after the last Ice Age, spreading over a large percent of the continent to form one of the most significant forest ecosystems in Europe. The third extension nomination has been developed in 2020 and proposes the inscription of additional 30 component parts, a considerable step towards the complete overall picture of post-glacial beech re-colonization process and beech ecosystem diversity across Europe. With this extension 8 additional European countries would join this property, including the Republic of Serbia. The extended property would consist of over 100 component parts in 20 European countries, a pan-European network of protected areas with joint protection and management goals to represent a platform for policy making and knowledge exchange. This paper presents the genesis of this extremely complex World Heritage property and the work done to expand it over the protected beech forests in Serbia, in preparation of the first Natural World Heritage nomination for the Republic of Serbia.
\end{abstract}

Key words: Natural World Heritage, beech forests, Republic of Serbia, nomination, UNESCO.
Извоg: Букове шуме су првобитно заштићене 2007. године као добро светске баштине Нейакнуйе букове шуме Карйайа (Словачка и Украјина). Након два наредна проширења, 2011. и 2017. године, ово добро светске природне баштине тренутно носи назив Древне и нетикнуйе букове шуме Карйайа и gруіих реіиона Европе (Албанија, Аусиирија, Беліија, Буіарска, Хрвайска, Немачка, Ийалија, Румунија, Словачка, Словенија, Шйанија и Украјина) и састоји се од 78 компоненти у 12 европских земаља, а са циљем да се очува генетички диверзитет букве, специјски и екосистемски диверзитет букових шума, њихова будућа обнова и ширење у односу на развојне и експлоатационе притиске са којима су букове шуме суочене и на биодиверзитет који одржавају. Додатно, ово добро светске природне баштине има за циљ да представи експанзију букве након последњег леденог доба, када је ова врста заузела велики део континента, градећи најзначајније шумске екосистеме у Европи. Трећом номинацијом проширења овог добра, припремљеном током 2019. године, предлаже се уписивање додатних 30 компоненти, што представља значајан корак ка комплетирању опште слике пост-глацијалне колонизације букве и диверзитета букових шума широм Европе. Овим проширењем се добру светске природне баштине придружује још 8 европских држава, међу којима је и Република Србија. Проширено добро би се састојало од преко 100 компоненти у 20 европских земаља, као паневропска мрежа заштићених подручја са заједничким циљевима заштите и управљања, али и као платформа за развој политика и размену знања. У раду се представља настанак овог веома комплексног добра светске баштине и активности на његовом проширењу на заштићене букове шуме у Србији у оквиру припрема прве номинације природне баштине за Републику Србију.

Кључне речи: светска природна баштина, букове шуме, Република Србија, номинација, UNESCO. 


\section{INTRODUCTION}

\section{Why protect beech forests?}

European beech (Fagus sylvatica L.) is a deciduous tree species endemic to Europe, therefore the beech forests are exclusively European vegetation type (Vološčuk et al., 2013). With almost pan-European distribution, beech forests represent one of the most significant forest types of the northern hemisphere Temperate Broadleaf Forest Biome (Vološčuk, 2013a; Karadžić, 2018). Total area of the beech dominated forests in Europe is estimated at approximately 15 Mha, excluding the Caucasian Mts, with the largest forested areas in the south-eastern European mountains, Carpathians, Dinaric and Balkan Mountains, as well as in the central and southern Germany and France (Brunet et al. 2010; Vološčuk, 2013b).

Beech originated in the Tertiary Epoch and, having survived the alternating glacials of the Quaternary Period in refuge areas of the southern and southeastern Europe, entered the expansion phase after the last Ice Age with high ecological competitiveness, to colonize the continent over a wide spectrum of habitats (Vološčuk, 2013a, 2014; Magri et al., 2006; Knapp \& Fichtner, 2011). However, beech is best adapted to humid climate, thriving in regions without a pronounced dry season, with mild winters and humid summers, which makes it most abundant broadleaved tree species in Central Europe and in mountain regions of Southern Europe (Karadžić, 2018; Rugani et al. 2013; Knapp \& Fichtner, 2011).

As one of the main tree species building up forest ecosystems in Europe (Vološčuk, 2014; Rugani et al. 2013), beech deeply influences the internal forest climate by its dense foliage and canopy shape, significantly reducing the amount of light reaching the interior of beech forests (Karadžić, 2018), conditioning the soil formation, regeneration cycles, food chains and supporting specific biodiversity (Vološčuk, 2014). Beech forests are among the most valuable terrestrial ecosystems in Europe, as they support a significant part of European biodiversity (Knapp \& Fichtner, 2011; Vološčuk et al. 2013). It is estimated that up to 10,000 species of animal live in beech forests (Britz, 2015; Vološčuk et al. 2013).

If left undisturbed, the landscape of the temperate Europe would be dominated by beech forests as the climax ecosystem. However, beech forests today only cover a fraction of their potential natural distribution area (Commarmot et al., 2013; Britz, 2015; Knapp \& Fichtner, 2011; Vološčuk et al. 2013; Ibisch, 2014). The natural beech forests are scarce in Europe, accounting for only $2.8 \%$ of the European forests (Russian Federation excluded), having been exposed to the devel- opment pressures for centuries, i.e. the expansion of settlements, infrastructure and agricultural land, as well as the forest utilization (Knapp \& Fichtner, 2011; Vološčuk, 2013a; Sabatini et al. 2018; Commarmot et al., 2013; Rugani et al. 2013; Bengtsson et al. 2000). Beech forests that escaped clearance in front of agriculture, settlements or infrastructure, are largely managed for timber production, as beech ranks high in terms of wood quality. The beech forest management aimed for timber production, however, has far-reaching effects on the forest structure and biodiversity (Lonsdale et al. 2008; Winter, 2012).

\section{Forest management in Europe}

Due to the high human population densities, temperate broadleaved forests in Europe have been transformed by human activities to a larger extent than any other forest biome (Brunet et al., 2010; Knapp \& Fichtner, 2011; Vološčuk et al. 2013).

First forest order prescribing the management in all forested areas of south-central Europe was passed in the second half of XVIII century by Maria Theresa. It was in force up to the year 1852, when the first Austrian forest act was passed, prohibiting clearing and reduction of forests and prescribing the basic measures for sustainable forest management, added that special forest units for its implementation were organized (Hahn \& Fanta, 2001).

Compared to the XVIII century forestry, which focused on ways of ensuring natural regeneration or selective cuttings in shelterwood systems, the middle XIX century forestry strongly favored the economic approach to attaining the maximum forest rent. The creation of pure, even-aged conifer stands, fast-growing and providing high-quality wood, replaced the mixed broadleaf stands, area regulation and balanced distribution of age classes. A definite rotation length striving for a constant maximum annual yield became the canon of forest management (Agnoletti et al. 2009; Britz, 2015). Most of the traditional silvicultural treatments focused on timber production have considerably shortened forest development cycle, up to only $10-40 \%$ of the potential lifespan of tree species, thus originating homogenous, even-aged stands which lack the typical structural attributes of old forests (Barbati et al. 2012).

In managed forests, deadwood occurs mainly as a logging waste and stumps, whereas large logs and snags are rare. Surveys from several European counties have shown that the average dead wood volume in present day production forests is less than $10 \mathrm{~m}^{3} /$ ha. The amount of deadwood in unmanaged forests is 10-20 times higher than in managed, production forests (Christensen et al. 2005). It should be noted 
that only 5\% of European forests include trees older than 140 years, while area covered with old-growth forests in Europe is estimated to be approximately 3 Mha, mostly located in Sweden and Finland, as well as in the mountains of central and eastern Europe, most notably the Carpathian Mountains (EEA, 2016).

\section{Beech forests management}

Shelterwood forest management system was dominant way of beech forest utilization in most European countries from XIX through most of XX century (Brunet et al., 2010; Hahn \& Fanta, 2001; Knapp \& Fichtner, 2011). Shelterwood management involves the thinning of forest canopy after a mast year to establish a dense natural regeneration, after which the remaining seed trees are cut, resulting in singlelayered and even-aged stands, with small amount of dead wood and small capacity of harboring beech forest related biodiversity.

In contrast, beech forests managed with selective, single stem or group harvest systems retain the multi-layered and multi-aged stand structure, but this type of forest management also significantly reduces the amount of dead wood by removing the old and senescent trees, negatively effecting the forest dependent biodiversity (Brunet et al., 2010; Christensen et al. 2005). Nonetheless, the selective harvest is often referred to as close-to-nature forestry, nature-based forestry, near-natural forestry, continuous cover forestry, multi-aged forestry, green-tree retention, nature-oriented silviculture, naturalistic silviculture or ecological silviculture (Matović et al. 2019).

The most biodiversity damaging forest management system is a clear-cut system (EEA, 2016; Hahn \& Fanta, 2001). Extensive clear-cutting produces a rapid shift in structure and loss of habitat, while tree extraction involves the use of large, heavy machinery that causes damage to the soil, vegetation and other features, all of which is decidedly damaging to overall biodiversity (Hahn \& Fanta, 2001).

Beech forests with no or low human impact, although rare in Europe, can still be found locally and in most cases are related to the extreme inaccessibility and remoteness of their habitats (Europarc-España, 2017; Sabatini et al. 2018; Britz, 2015; Commarmot et al., 2013). Most of these undisturbed beech forests have survived in mountainous areas, mainly in the geographic regions of the Carpathians, the Balkans and the Alps (Commarmot et al., 2013).

Since nature protection and close-to-nature forest management are gaining more recognition in Europe, the awareness of the significance of such undisturbed forests as reference sites has arisen, for they provide insight into the structure and development of natural forests to accommodate the ecologically-based forest management (Diaci, 1999; Willim et al. 2019; Christensen et al. 2005; Vandekerkhove et al. 2009; Rugani et al. 2013; Bengtsson et al. 2000).

Undisturbed beech forests are characterized by the uneven age structure, representing all beech development phases, from seedlings to the very old, senescent trees. Clear vertical diversification leads to the gap dynamics regeneration, where the mortality of canopy trees is a prerequisite for the regeneration of beech (Wirth et al. 2009; Glatthorn et al. 2018). Since beech is a shade-tolerant tree species, groups of seedlings can establish under small canopy openings and persist for longer periods of time, sustaining themselves only on scarce, moving sun flecks, even after canopy gaps are closed (Rugani et al. 2013).

Along with the significant amounts of dead wood, both standing and in soil, the gap dynamics generates a complex, multi-layered stand structure of undisturbed beech forests, with natural species composition and ecological processes (Europarc-España, 2017; Christensen et al. 2005 Rugani et al. 2013; Glatthorn et al., 2018). Deadwood is an important component in the functioning of forest ecosystems, as it plays an important role in biogeochemical cycles, trophic chains, natural regeneration, and is an important element in carbon storage, as well as in providing key niches for many species (Vandekerkhove et al. 2009; Harmon et al. 1986).

The importance of preserving these forests for biodiversity conservation is well recognized (Barbati et al., 2012; EEA, 2016), as they are vital for biodiversity dependent on the undisturbed forest characteristics, which includes many of the rare and threatened species (Kirchmeir \& Kovarovics, 2016a; Sabatini et al. 2018). The scarcity of such forests implies that related biodiversity has become threatened (Bengtsson et al. 2000), which has accounted for these forests to become one of the key issues in the conservation policies of the European Union (Europarc-España, 2017; Knapp \& Fichtner, 2011). Old-growth forests are considered as "reference stands" for each forest type, including the beech forests, regarding the Habitats Directive and the Natura 2000 network. Moreover, they provide the forestry criteria to achieve conservation objectives of species or habitats, especially in protected areas (Europarc-España, 2017; Sabatini et al. 2018).

It can be argued that under such conservation policies and tendencies of the EU, the initiative arose to create a Pan-European internationally protected area which would include "the best of the last" (IUCN 2007; IUCN 2011) fragmented remnants of the undisturbed, natural and close-to-natural beech forest ecosystems (Knapp \& Fichtner, 2011). The beech forest 
protection initiative lead to the inscription of European beech forests on the Natural World Heritage list, as well as to three extension nominations so far, with the goal to synchronize management policies across the European countries, assuring the survival of these forest types, which are characteristic for Europe and globally significant (Vološčuk, 2013a).

\section{World Heritage - the Convention and the UNESCO Programme}

The Convention Concerning the Protection of the World Cultural and Natural Heritage, known as the World Heritage Convention (furthermore referred to as the Convention), is one of the most ratified international agreements, with 193 signatory countries. Created in 1972, the mission of the Convention is to identify and protect the world's natural and cultural heritage considered to be of Outstanding Universal Value, which is so exceptional as to transcend national boundaries and to be of common importance for present and future generations of all humanity. As such, the permanent protection of this heritage is of the highest importance to the international community as a whole (UNESCO, 2017; IUCN, 2006).

In order to provide better insight and presentation of World Heritage sites, a World Heritage List was established, listing the sites under two categories: Cultural and Natural World Heritage. So far, 1092 sites in 167 countries of the world have been listed, 845 of which are Cultural Heritage sites, while only 209 are Natural Heritage sites and 38 are mixed sites including both natural and cultural world heritage (https://whc. unesco.org/en/list/).

Within its World Heritage Programme, the UNESCO (United Nations Educational, Scientific and Cultural Organization) facilities the protection of cultural and natural heritage sites on behalf of the international community. UNESCO World Heritage Center in Paris, established in 1992, is the main focal point and coordinator within UNESCO for all matters related to the Convention (https://whc.unesco.org/). However, the implementation of the Convention is entrusted to the World Heritage Committee, which decides on whether a property is inscribed on the World Heritage List, examines reports on the state of conservation of inscribed properties and requests State Parties to take actions when properties are not being properly managed. The World Heritage Committee consists of representatives from 21 State Parties and holds yearly sessions. Even though Committee member's term of office is 6 years, most State Parties choose it voluntarily to be only 4 years, in order to give other State Parties an opportunity to take part in the Committee (https:// whc.unesco.org/en/committee/).
Each State Party to the World Heritage Convention is entitled to nominate a property on its territory to be protected under the Convention and inscribed on the World Heritage List. State Parties need to submit to the World Heritage Committee an inventory of properties on their territory which are suitable for the inscription, the inventory being referred to as a Tentative List. A property cannot be nominated by a State Party unless it was first inscribed on the Tentative List (UNESCO, 2017; https://whc.unesco.org/en/tentativelists/). No less than one year after this inscription the State Party can submit the nomination dossier to the World Heritage Centre, which then forwards it to the corresponding Advisory Bodies of the World Heritage Committee: ICCROM (International Centre for the Study of the Preservation and Restoration of Cultural Property), ICOMOS (International Council on Monuments and Sites) and IUCN (International Union for Conservation of Nature).

A nominated Cultural Heritage will be evaluated by ICCROM and ICOMOS, Natural Heritage by IUCN, while mixed properties will be evaluated by all of the Advisory Bodies. After a nominated property is independently evaluated by the Advisory Bodies, they respectively provide the World Heritage Committee with the evaluation and their recommendation regarding the inscription decision, which is to be voted on by the World Heritage Committee on the annual Sessions of the World Heritage Committee (UNESCO, 2017; https://whc.unesco.org/en/faq/9/).

The success for inscriptions of natural and mixed World Heritage properties has ranged between 20\% and $80 \%$ of the submitted nominations per year since the begging of the implementation of the Convention. In recent decades, the average number of nominations has risen, but the rate of inscription has fallen to approximately 30 to $50 \%$ per year, partly due to the fact that many of the most iconic natural properties have been inscribed in the early years of the Convention, which is reflected in the high rate of inscription at this time. However, there is a noticeable trend of stricter application of the Operational Guidelines over time by the World Heritage Committee and by IUCN as its Advisory Body on Natural Heritage (Badman et al., 2008).

\section{Outstanding Universal Value}

The World Heritage Committee sets the precise criteria for the inscription of properties on the World Heritage List, as well as the requirements for their nomination and the future management and reporting, all provided by the document entitled Operational Guidelines for the Implementation of the World Heritage Convention, which is frequently revised by the Com- 
mittee as to reflect the new concepts, knowledge or experiences, last updated in 2017 (UNESCO, 2017; https://whc.unesco.org/en/guidelines/).

To be inscribed on the World Heritage list, a property must meet one or more of the 10 Outstanding Universal Value criteria, of which I-VI apply to cultural and VI-X to natural heritage. A nominated property must also meet certain conditions of integrity (cultural and natural properties) and/or authenticity (cultural properties only). Natural sites nominated individually or serially, besides meeting one or more OUV criteria (VI-X), need to meet the stringent requirements of integrity (UNESCO, 2017; IUCN, 2006).

IUCN (2006) suggests the following principles in understanding the concept of Outstanding Universal Value (further on: OUV) of the Natural World Heritage:

- Outstanding: properties should be exceptional: World Heritage Convention sets out to define the geography of the superlative - the most outstanding natural and cultural places on Earth;

- Universal: as the scope of the Convention is global, so the inscribed properties should hold the significance to all people of the world; properties cannot be considered from a national or regional perspective;

-Value: what makes a property outstanding and universal is its 'value', the defined worth of a property in terms of its global importance, based on a set of clear standards or criteria.

A Natural World Heritage must have adequately delineated boundaries to incorporate all the attributes which convey the OUV and to ensure the integrity and/ or authenticity of the property. The boundaries should include sufficient areas immediately adjacent to the area of OUV in order to protect the property's heritage values from direct effect of human encroachments and impacts of resource use outside of the nominated area (UNESCO, 2017).

For all the natural properties, bio-physical processes and landform features should be relatively intact. However, it is recognized that no area is totally pristine and that all-natural areas are in a dynamic state, and to some extent involve contact with people. Human activities, including those of traditional societies and local communities, may be consistent with the OUV if they are ecologically sustainable. Additionally, a nominated property must have an adequate protection and management system in place to ensure its safeguarding, including appropriate legal, boundary and buffer zone provisions and a management plan or system ensuring that the uses supported by the property are ecologically and culturally sustainable (UNESCO, 2017; IUCN, 2006).
Even though there is no official form of a management plan set by UNESCO (Kruse et al., 2009), it is a necessary tool to achieve that the World Heritage properties are managed in a way to ensure that their OUV, including the conditions of integrity and/ or authenticity, is sustained or enhanced over time (UNESCO, 2017; IUCN, 2006). As there are still many State Parties of the World Heritage Convention which do not have the instrument of a management plan in their national nature protection legislative, a proof of a functioning management system needs to be provided in the obligatory management chapter of a nomination dossier, along with the land ownership information and means of implementing the protective measures (Kruse et al., 2009).

For the management of a transnational property, the establishment of a joint management committee or similar body to oversee the management of the whole of a trans-boundary property is recommended (UNESCO, 2017; Kruse et al., 2009). Common elements of an effective management system of a complex WH property include a shared understanding of the property by all the stakeholders, their involvement in planning, implementation, monitoring, evaluation and feedback cycles, as well as the allocation of necessary resources, capacity-building in an accountable and transparent management system (Vološčuk et al. 2013).

\section{The inscription of European beech forests on the World Heritage list}

The first effort to nominate European beech forests as Natural World Heritage (hereinafter referred to as NWH) occurred in 2003, when Slovakia nominated a serial natural property consisting of undisturbed, complex beech forests in the Carpathian Mountains, near the Ukraine border (IUCN, 2007). However, this nomination was not discussed at the $28^{\text {th }}$ Session of the World Heritage Committee, at the request of the State Party, i.e. Slovakia (WHC, 2004), following the IUCN recommendation for a joint nomination by the State Parties of Slovakia and Ukraine as the only efficient approach at conservation of these bordering Carpathian forests (IUCN, 2007; WHC, 2007).

On January $31^{\text {st }} 2006$, the State Parties of Slovakia and Ukraine have jointly submitted the nomination concerning the protection of remnant primeval beech forests in the Carpathians as Natural Heritage (Anonymous, 2006; IUCN, 2007; WHC, 2007). At its $31^{\text {st }}$ Session, the World Heritage Committee (hereinafter referred to as WHC) adopted in 2007 the Decision 31 COM 8B.16, inscribing these undisturbed beech forest ecosystems on the World Heritage list as the Primeval Beech Forests of the Carpathians (Slovakia and 
Ukraine), under Criterion IX (WHC, 2007; UNESCO, 2017). Criterion IX requires properties to "be outstanding examples representing significant on-going ecological and biological processes in the evolution and development of terrestrial, fresh water, coastal and marine ecosystems and communities of plants and animals". Properties nominated under criterion IX must be of "sufficient size and to contain the necessary elements to demonstrate the key aspects of processes that are essential for the long-term conservation of the ecosystems and the biological diversity they contain", as the condition of integrity (UNESCO, 2017; IUCN, 2006; Badman et al., 2008).

Primeval Beech Forests of the Carpathians property was inscribed as a transnational serial property of 10 components in Slovakia (4) and Ukraine (6), the component parts of which represent outstanding examples of undisturbed and complex pure-stand beech forests, exhibiting the most complete and comprehensive ecological patterns and processes across a variety of environmental conditions (WHC, 2007). Protection of these primeval beech forests as World Heritage was aimed at conserving beech forest ecosystems for future generations by protecting valuable genetic pull of European beech and the beech forest communities.

In June 2011 at the $35^{\text {th }}$ Session held in Paris, the WHC adopted the Decision 35 COM 8B.13, approving the first extension of the Primeval Beech Forests of the Carpathians (Slovakia and Ukraine) to include the Ancient Beech Forests of Germany, thus becoming the Primeval Beech Forests of the Carpathians and the Ancient Beech Forests of Germany (Slovakia, Ukraine and Germany), inscribed under Criterion IX as a transnational serial property consisting of 15 components - 6 in Ukraine, 4 in Slovakia and 5 in Germany (WHC, 2011).

The extension nomination was prompted by the IUCN evaluation of the Primeval Beech Forests of the Carpathians (Slovakia and Ukraine) nomination, pointing out that the nominated property was not representative of all types of beech forests and that Germany had some significant old-growth beech forests which may extend the coverage of European beech forests on the World Heritage List (IUCN, 2007; Britz et al. 2009). The added old-growth beech forests allowed the WH property to better represent European beech forests, their history and evolution, considering that Germany is the heartland of their distribution, with about one-fourth of the beech natural range (Britz et al. 2009; Vološčuk et al. 2013).

The German nomination clearly shifted the focus of the OUV within the Criterion IX: the initial nomination considered the component parts in the Carpathians to best represent the natural, undisturbed beech forests, whereas the German components put the emphasis on the postglacial continental-wide expansion of beech forests. The first extension was a major step towards a comprehensive outlook on the OUV of this WH property as the outstanding series of undisturbed European beech forests to effectively preserve these unique forest ecosystems in Europe for future generations, while adopting the need to depict a broader picture was aimed at presenting the still ongoing beech postglacial expansion process (Kirchmeir \& Kovarovics, 2016a). To fully represent the history and evolution of the beech forests, the property would need the inclusion of different regions of Europe the beech has reached in its continental-wide spread (Vološčuk, I. 2013a, Vološčuk et al. 2013), considering that the beech forests differ amongst phytogeographic zones, forming distinctive forest types of characteristic species composition, spatial structure, dynamics and overall diversity - including the genetic diversity of beech, as differing adaptations on abiotic conditions, the altitude, topography and macroclimate, as well as the nutrient and water availability (Vološčuk, I. 2013b).

In the extension decision the WHC "commends the States Parties of Ukraine, Slovakia and Germany for their on-going commitment to ensure a comprehensive approach to conserving the primeval and ancient beech forests of Europe and for their exploration of the potential for the World Heritage Convention to further these efforts by cooperating with the support of IUCN and the World Heritage Centre, with other interested States Parties towards a finite serial transnational nomination in order to assure the protection of this unique forest ecosystem" (WHC, 2011). Following this recommendation, the German Federal Ministry for Environment, Nature Conservation, Building and Nuclear Safety (BMUB) launched a Research and Development Project titled European World Heritage Beech Forests, with the goal of "defining the scope of a possible finite European extension nomination to the existing trilateral World Heritage property" (Ibisch, 2014). The project was commissioned by the German Federal Agency for Nature Conservation (BfN) and implemented by the Centre for Econics and Ecosystem Management (CEEM) at the Eberswalde University for Sustainable Development (HNEE).

The screening process lasted over two years and provided in 2014 the first comprehensive overview of ancient and primeval beech forests in Europe, which listed 126 sites (Ibisch, 2014), later to be known as the Longlist. Based on the inscription criteria, the 64 suitable extension sites formed the so-called Vienna Shortlist, setting groundwork for the next extension nominations (Kirchmeir \& Kovarovics, 2016). Other significant project results included the delineation 
of the 12 European Beech Forest Regions (Figure 1), which was referenced in the future extension nominations of the property.

State Parties hosting at least one of the sites on Vienna Shortlist were invited to participate in the upcoming extension nomination, resulting in an assembly of 11 countries: Albania, Austria, Belgium, Bulgaria, Croatia, Italy, Poland, Slovenia, Spain, Romania and Ukraine. Poland subsequently decided to withdraw from the nomination, which ultimately included 10 European countries and 63 component parts in 32 protected areas (Kirchmeir \& Kovarovics, 2016). The extension was inscribed on the World Heritage List by the Decision 41 COM 8B. 7 of the WHC, which has again considered future extensions of the property towards a finite component composition based on the scientific criteria, such as were used in the Screening Study 2012-2014 (WHC, 2011).

After two extensions, the World Heritage site is currently named the Ancient and Primeval Beech Forests of the Carpathians and Other Regions of Europe (further on: AP BF CORE), which consists of 78 component parts ${ }^{1}$ in 43 protected areas and covers 92023.14 ha in 12 European countries: Albania, Austria, Belgium, Bulgaria, Croatia, Germany, Italy, Romania, Slovakia, Slovenia, Spain and Ukraine. In Table 1 we have compiled all the basic data of all currently inscribed AP BF CORE component parts, segregated in line with the nomination they were inscribed in, in order to provide better understanding of this extremely complex NWH property which has been developing for almost two decades under the World Heritage Convention.

\section{Results and Discussion}

At the initiative of the Swiss Confederation, the preparation of another serial transnational AP BF CORE extension nomination was underway in 2018. Ultimately, the following 10 countries took part in the extension nomination: Bosnia and Herzegovina, Czech Republic, France, Italy, Poland, Serbia, Slovakia, Switzerland, North Macedonia and Montenegro. The nomination bearer, the Swiss Confederation, delivered the extension nomination dossier to the World Heritage Centre in January 2020. Table 2 presents the nominated component parts of the 2020 Extension Nomination Proposal (further on: 2020ENP), compiled with the corresponding data on the sizes of the core and the buffer zone and the protected area they belong to.

From 2019 on, the nomination dossier preparation was guided by the E.C.O Institute for Ecology from Klagenfurt, Austria (further on: the Coordination Office), which experience in preparing the previous extension of the property has had the major influence on the process, making certain that a solid nomination proposal with high inscription chance was elaborated in 2020. To aid the preparation of the nomination dossier, the Coordination Office has prepared the Nomination Handbook, where all the zonation and description concepts were elaborated to reach a common understanding of the inscription criteria.

The State Parties have assigned the Focal Points for the nomination process to coordinate the 2020ENP activities and tasks in their respective countries, which were invited by the Coordination Office to attend four technical meetings during the preparation of the 2020ENP, in Klagenfurt (October 2018), Bern (May 2019), Belgrade (September 2019) and Vienna (January 2020). The meetings have had an important role in the nomination preparation, as the application of the inscription criteria and selected component parts were discussed in detail, providing the experts with a clear notion on how to proceed further with the nomination tasks.

This nomination needed to better represent beech forests across Europe and to close some significant distribution gaps, in order to represent all beech forest regions and protect the last remnants of ancient and primeval European beech forests over a full scope of environmental conditions. Most notable gaps were in the Balkan Peninsula, as well as in the far-western European territories (Figure 2).

\section{Inclusion of the Republic of Serbia in the Ancient and Primeval Beech Forests of the Carpathians and Other Regions of Europe World Heritage site}

The Republic of Serbia has appointed the Institute for Nature Conservation of Serbia (further on: the Institute) to prepare the nomination on the technical level and the Ministry of Environmental Protection to guide the process on the national level. Serbian National Commission for UNESCO within the Ministry of Foreign Affairs was involved in the nomination process as well. The dossier was signed by the UNESCO ambassador of the Republic of Serbia, appointed by the Serbian Government.

To prepare the nomination dossier, the Institute has collaborated with the managers of the nominated protected areas, as well as with the Institute for Nature Conservation of Vojvodina Province, as nomination includes component parts on the territory of Vojvodina Province of the Republic of Serbia. All the mentioned stakeholders were invited to participate in the technical meeting held in Belgrade and co-organized by the Institute in September 2019.

\footnotetext{
${ }^{1}$ A technical error should be noted in the Decision 41COM 8B.7. on the latest extension inscription, where it states that the newly formed property includes 77 components (WHC, 2017). The complete list is provided in Table 1.
} 


\section{First Serbian Tentative List submission (2018)}

State Parties hosting the suitable sites for the next extension of AP BF CORE World Heritage site according to the Vienna Shortlist were invited in late 2017 to add the extension components on their UNESCO World Heritage Tentative Lists, as the first step towards the nomination. The deadline for submission of all documents to the World Heritage Centre to be considered by the WHC in the following year was set at the $1^{\text {st }}$ of February (UNESCO, 2017). Despite the short deadline, on the $28^{\text {th }}$ of January 2018 , the Republic of Serbia added the components intended for the next AP BF CORE extension to its Tentative List. Only four countries, Montenegro, Poland, Serbia and Switzerland, added the extension components to their respective Tentative Lists in 2018.

The Institute prepared the first set of components which included 11 Forest Reserves selected on the basis of their naturalness and the diversity of beech forest communities, including several relict and endemic species and/or plant communities (Table 3). The objective at the time was to represent the diversity of the ancient and primeval beech forests in Serbia, focused on the Moesian region, as the dominant beech region of the country. The oldest and predominantly pure-stand beech forests under the strict protection were selected, including some of the first protected areas in Serbia, the oldest one being the Strict Nature Reserve Zeleničje, established in 1948. The longlasting strict protection has provided undisturbed development resulting in some of the oldest preserved forests in Serbia in general. With exceptional site diversity, the selected components from Serbia would greatly improve the representation of the development history of beech forests of the Balkan Peninsula, in the context of OUV of this property, as well as they would represent a significant addition considering the role of the Balkan Peninsula in the historical and the contemporary beech forest development, maintaining some of the oldest beech forest ecosystems in Europe.

Having in mind that at this point the Coordination Office was not yet contracted by the Swiss Confederation to guide the nomination process on technical level, while lacking the time to research and comprehend all the inscription criteria, the selection of the components entered on Serbian Tentative List in 2018 was not in line with some of the criteria set by previous extensions. Most notable weakness of the first selection of components added onto Serbian Tentative List were the small sizes of the components, with the smallest one being just 0.45 ha of size (Table 3). However, these are not small, isolated forested islands, but are incorporated into continuous forest cover.
Nevertheless, the minimal size threshold of 50 ha was set by the WHC in the Decision 41 COM 8B.7 (WHC, 2017), which required an overall revision of the Serbian component parts selection.

\section{Second Serbian Tentative List submission (2019)}

Klagenfurt technical meeting of late 2018 was the kick-off meeting of the nomination dossier preparation process led by the Coordination Office. The meeting had revealed that the most of components on the Serbian Tentative List did not compile with the 50 ha minimum size criteria, requiring their withdrawal from the Tentative List and the composing of a new Tentative List Submission Form by the $1^{\text {st }}$ of February 2019. For the participating State Parties which had not submitted the extension components on their Tentative Lists in 2018, the Klagenfurt technical meeting was the starting point of the entire nomination process.

All countries participating in the later nomination had submitted their extension components on the Tentative List by the deadline, with coordinated contents of the Tentative List Submission Forms in regard to the common nomination ahead. As of 2019, the World Heritage Committee regards a joint effort of the following ten State Parties to further extend the existing NWH property of AP BF CORE: Bosnia and Herzegovina, Czech Republic, France, Italy, Montenegro, North Macedonia, Poland, Serbia, Slovakia and Switzerland, out of which eight State Parties were not represented in the existing NWH property.

According to the conclusions drawn from the meeting in Klagenfurt, the Institute further studied other strictly protected beech forests in Serbia to revise component selection for the upcoming extension of the AP BF CORE World Heritage site. Eight Level I Protection Regime (further on: Lvl I PR) localities within three Serbian national parks - Fruška gora, Tara and Kopaonik, were included on the Serbian Tentative List on the $31^{\text {st }}$ of January 2019.

Beech forests of Fruška gora NP in Vojvodina Province of Serbia have been selected as the only suitable component in the whole Pannonian BFR for future extension of AP BF CORE. The inclusion of the ancient beech forests within the two Lvl I PR localities of Fruška gora NP, Papratski do and Ravne, would first represent the Pannonian BFR within the future extended property which was regarded as significant additional value of these ancient forests.

The representation of the Moesian-Balkanic BFR was much improved by the revised selection of six component parts from central Serbia, the two Lvl I PR localities of Tara NP, Zvezda and Klisura Rače, and the 
four Lvl I PR localities of Kopaonik NP: Kozje stene, Duboka, Metode and Jelak. Within the existing property the Moesian-Balkanic BFR was underrepresented by two components in north Albania and one cluster component of nine component parts on the Central Balkan massif in Bulgaria, considering that the variability of beech forest communities within the BFR depends on the differences in the species pool, geological bedrock diversity, soil types, altitudinal zones, etc. All the localities include primeval beech forests in and around deep river gorges or canyons, as habitats of strong refugial character reflected in the presence of endemic and relict species and/or relict communities, emphasizing the refugial characteristics of Balkan Peninsula during the Ice Ages, reflected the evolution history and the diversity of the beech forests.

\section{The nominated components from Serbia}

The zonation design which followed the elaborated guidelines of management requirements has revealed that not all of the selected component parts from Kopaonik NP could be nominated, although hosting scientifically valuable primeval beech forests, on accounts of the surrounding winter sports infrastructure in Kopaonik NP.

Winter tourism is the most significant human influence in Kopaonik NP, as the major winter sports center in Serbia is located around the highest peak (Pančićs Peak, $2017 \mathrm{~m}$ a.s.l.) in the southern part of the Park, spreading over 800 ha, with 25 ski-lifts, 62 $\mathrm{km}$ of Alpine skiing routes and $15 \mathrm{~km}$ of Nordic skiing routes. Around this ski-resort grew an urbanized area called Suvo Rudište, with over 10.500 accommodation units (Milovanović, 2019). Skiing activities on Kopaonik Mt. date back to 1930's, while the ski-center dates back to 1964, when the first ski-lift was opened (https://www.skijanje.rs/istorija/istorija-skijanja-usrbiji/pocetci-skijanja-na-kopaoniku/). It should be noted that almost all ski related infrastructure is concentrated around this area, while the rest of the Park remains unaffected.

The buffer zone of the components located within Duboka and Brzećka river gorges in the SE part of the Park, Duboka, Metođe and Jelak, would inevitably be exposed to the negative impact of Kopaonik ski-center development. Since we could not guarantee the adequate management requirements in the buffer zone, it was necessary to exclude these localities from the final nomination of components from the Republic of Serbia.

The final five nominated component parts include two Lvl I PR localities of Fruška gora NP, Papratski do and Ravne, two Lvl I PR localities of Tara NP, Zvezda and Klisura Rače, and one Lvl I PR locality of Kopaon- ik NP: Kozje stene. Components from Tara NP and Fruška gora NP form component clusters, with two component parts embedded in a mutual buffer zone, while Kozje stene component represents a single component within Kopaonik NP.

All the component parts are protected by the Law on National Parks ("Official Gazette of RS", No. 84/2015), Law on Nature Protection ("Official Gazette of RS”, No. 36/09; 88/2010; 91/2010, 14/2016 and 95/2018) and the Decree on Protection Regimes ("Official Gazette of RS", No. 31/2012) and belong to the ecologically important areas of the ecological network of the Republic of Serbia, which also include Important Bird Areas (IBA), Prime Butterfly Areas (PBA), Important Plant Areas (IPA) and Emerald network sites, as set by the Decree on Ecological Network (“Official Gazette of RS", No. 102/2010), all referenced in Table 4.

By the Law on Nature Protection (Official Gazette of RS, No. 36/09; 88/2010; 91/2010, 14/2016 and 95/2018) and the Decree on Protection Regimes (Official Gazette of RS, No. 31/2012), Level I Protection Regime of protected areas in Serbia prohibits all uses of natural resources, any kind of construction and all human activities, except for scientific research, monitoring of natural processes, controlled visits for educational and cultural purposes, implementation of necessary protective measures in case of natural disasters or diseases and maintenance of significant objects (e.g. electric transmission lines). All visits must be conducted in consultation with the managers to assure that the visitors compile with regulations, not to step away from the paths or trails, not to disturb or collect any organism and to leave no trace behind. Management goal in Level I Protection Regime is to preserve natural ecosystems and their natural dynamics undisturbed. If necessary, minimal interventions can be undertaken, but no wood is to be extracted, except if it can be expected to lead to a disease spread and further forest ecosystem damage. The managers can only apply sanitary measures after acquiring the permit from the Ministry of Environmental Protection on the basis of the expert opinions of the Institute for Nature Conservation of Serbia or the Institute for Nature Conservation of Vojvodina Province, depending on the location of the protected area in regard to the administrative division of the country.

All national parks in Serbia are protected by the Law on National Parks ("Official Gazette of RS", No. 84/2015) and their management is entrusted to the public enterprises, namely for the three relevant National Parks: PE "Nacionalni park Kopaonik", PE "Nacionalni park Tara" and PE "Nacionalni park Fruška gora". National Parks are managed according 
to the ten-year management plans and annual management programs, developed in accordance with the Institute for Nature Conservation of Serbia or the Institute for Nature Conservation of Vojvodina Province and approved by the Ministry of Environmental Protection.

\section{CONCLUSION}

Widely distributed in Europe, beech forests are one of world's most unique ecosystems, accounting for a significant part of the northern hemisphere Temperate Broadleaf Forest Biome Vološčuk et al. 2014). The phenomenon of a single tree species dominating forest vegetation over a major part of the entire continent is unique to Europe (Knapp \& Fichtner 2011). The postglacial forest development of beech, forests and their spread throughout Europe is an outstanding example of continent-wide development of terrestrial ecosystems and communities (Knapp \& Fichtner, 2011; Magri et al., 2006). Considering the past, present and future development pressures on natural forest ecosystems in Europe, preserving of ancient and primeval beech forests is regarded as a globally important task.

Initiative to represent and preserve the beech forest ecosystems by the World Heritage Convention for future generations led to the establishment of the complex serial, transnational World Heritage property, which has been developing for more than 15 years, since the initial Slovakia's proposal in 2003 and has included four World Heritage nominations so far, out of which two extension nominations. The third extension nomination was prepared in 2019 and submitted on $28^{\text {th }}$ of January 2020 , in order to complete the picture on continental-wide proglacial spread and diversity of the European beech forests.

The Outstanding Universal Value of the European beech forests is in their unique history and evolution as a prominent example of the ongoing re-colonization and development of terrestrial ecosystems after the last glacial period, due to the combination of postglacial climate changes and the extreme competitiveness, incredible ecological adaptability and distinct life strategy of the European beech, causing it to spread throughout Europe covering wide areas in a broad array of different beech forest types (Britz et al. 2009).

Ancient and Primeval Beech Forests of the Carpathians and Other Regions of Europe World Heritage site is aimed to reflect the post-glacial development process of the beech and to preserve the diversity of beech forest communities across Europe, considering that the beech forms different forest communities, according to the species pull available in different floristic regions of Europe, while occupying various distinctive combinations of environmental factors, including the climate, elevation belts and bedrock types.

The 2020 extension nomination proposes the inscription of additional 30 component parts and boundary modification of the 7 already inscribed component parts, aiming to better represent the OUV of the property, as well as to improve the integrity and protection of the existing property. In regard to the component type, 16 single components are nominated along with 8 component clusters. The nomination proposal concerns a total of 37 component parts located within 24 protected areas in 10 European countries: Bosnia and Herzegovina, Czech Republic, France, Italy, Montenegro, North Macedonia, Poland, Serbia, Slovakia and Switzerland. The 30 newly nominated component parts will contribute to the existing property with $15,986.96$ ha. The nominated component parts represent 9 Beech Forest Regions: Pyrenaic-Iberian, Central Mediterranean, Illyric, MoesianBalkanic, Subantlantic-Hercynic, Alpic, Carpathian, Atlantic and Pannonic, the latter not yet represented.

By this extension, the current inscribed serial transnational NWH property consisting of 78 component parts will be extended to a total of 108 component parts from 20 countries within 61 protected areas, across 11 out of 12 Beech Forest Regions in Europe, to better show the postglacial expansion process of beech and to demonstrate the development history of European beech forest ecosystems through the series of the most natural beech forest sites in 10 European countries. Furthermore, the nominated components achieve a more complete picture of the continental character, diversity and biogeographical distribution of beech forests, by adding new attributes to the existing property, increasing the integrity of the property and closing some distribution and diversity gaps. Namely, Serbian components will greatly improve the beech forest representation within two Beech Forest Regions, the Pannonian and the Moesian-Balkanic.

World Heritage property concerning the preservation of beech forests across 20 European countries will provide a solid platform for policy making, knowledge exchange and joint management activities, including research and monitoring opportunities across all the inscribed components and corridor development. The common goal of preserving the World Heritage property will result in a combined effort and foster a close international collaboration on all levels, including management, scientific research and governance, collaborating towards a common goal of management harmonization across different nature protection systems and practices. 
Beech Forests as World Heritage in aspect to the next extension of the Ancient and Primeval Beech Forests of the Carpathians and Other Regions of Europe World Heritage site

\section{TABLES AND FIGURES}

Table 1: The components comprising the Ancient and Primeval Beech Forests of the Carpathians and Other Regions of Europe Natural World Heritage site (Britz et al. 2009; Kirchmeir \& Kovarovics, 2016)

\begin{tabular}{|c|c|c|c|c|c|c|}
\hline & No. & State Party & Component part & Protected A rea & $\begin{array}{c}\text { Core } \\
\text { zone size } \\
\text { (ha) }\end{array}$ & $\begin{array}{c}\text { Buffer } \\
\text { zone size } \\
\text { (ha) }\end{array}$ \\
\hline \multirow{10}{*}{ 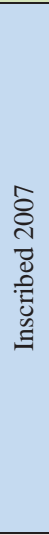 } & 1 & Ukraine & Stuzhytsia-Uzhok & U zhansky National Nature Park & 2532 & 3615 \\
\hline & 2 & Ukraine & Kuziy-Trybushany & \multirow{5}{*}{ Carpathian Biosphere R eserve } & 1369,6 & 3163,4 \\
\hline & 3 & Ukraine & M aramarosh & & 2243,6 & 6230,4 \\
\hline & 4 & Ukraine & Chornohora & & 2476,8 & 12925 \\
\hline & 5 & Ukraine & Svydovets & & 3030,5 & 5639,5 \\
\hline & 6 & Ukraine & Uholka-Shyrokyi Luh & & 11860 & 3301 \\
\hline & 7 & $\begin{array}{l}\text { Slovak } \\
\text { Republic }\end{array}$ & Vihorlat & V ihorlat Protected L andscape A rea & 2578 & 2413 \\
\hline & 8 & $\begin{array}{l}\text { Slovak } \\
\text { Republic }\end{array}$ & Stužica - Bukovské V rchy & $\begin{array}{l}\text { National N ature Reserve Stužica } \\
\text { within Poloniny N ational Park }\end{array}$ & 2950 & 11300 \\
\hline & 9 & $\begin{array}{l}\text { Slovak } \\
\text { Republic }\end{array}$ & Rožok & $\begin{array}{l}\text { National Nature R eserve Rožok } \\
\text { within Poloniny National Park }\end{array}$ & 67,1 & 41,4 \\
\hline & 10 & $\begin{array}{l}\text { Slovak } \\
\text { Republic }\end{array}$ & Havešová & $\begin{array}{l}\text { National Nature Reserve Havešová } \\
\text { within Poloniny National Park }\end{array}$ & 171,3 & 63,99 \\
\hline \multirow{5}{*}{ 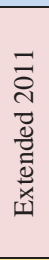 } & 11 & Germany & J asmund & Jasmund National Park & 492,5 & 2510,5 \\
\hline & 12 & Germany & Serrahn & M üritz National Park & 268,1 & 2568 \\
\hline & 13 & Germany & Grumsin & $\begin{array}{l}\text { Schorfheide-Chorin Biosphere } \\
\text { Reserve }\end{array}$ & 590,1 & 274,3 \\
\hline & 14 & Germany & Hainich & Hainich National Park & 1573,4 & 4085,4 \\
\hline & 15 & Germany & Kellerwald & K ellerwald-E dersee N ational Park & 1467,1 & 4271,4 \\
\hline \multirow{21}{*}{ 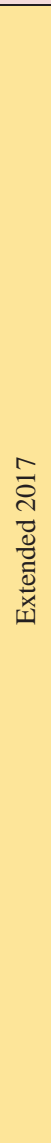 } & 16 & \multirow{2}{*}{ Ukraine } & Zacharovanyi Krai - Velykyi Dil & \multirow{2}{*}{$\begin{array}{l}\text { Zacharovanyi Krai National Nature } \\
\text { Park }\end{array}$} & 1164,16 & \multirow{2}{*}{1275,44} \\
\hline & 17 & & Zacharovanyi Krai - Irshavka & & 93,97 & \\
\hline & 18 & Ukraine & Synevyr - Vilshany & \multirow{4}{*}{ Synevyr N ational Nature Park } & 454,31 & 253,85 \\
\hline & 19 & Ukraine & Synevyr - Strymba & & 260,65 & 191,14 \\
\hline & 20 & Ukraine & Synevyr - Kvasovets & & 561,62 & 333,63 \\
\hline & 21 & Ukraine & Synevyr - Darvaika & & 1588,46 & 312,32 \\
\hline & 22 & Ukraine & Satanivska Dacha & $\begin{array}{l}\text { Podilski Tovtry National Nature } \\
\text { Park }\end{array}$ & 212,01 & 559,37 \\
\hline & 23 & Ukraine & Roztochya & Roztochya Nature Reserve & 384,81 & 598,21 \\
\hline & 24 & Ukraine & Gorgany & Gorgany Nature R eserve & 753,48 & 4637,59 \\
\hline & 25 & \multirow{2}{*}{ Spain } & $\begin{array}{l}\text { Hayedos de Picos de Europa - } \\
\text { Cuesta Fría }\end{array}$ & \multirow{2}{*}{ Picos de Europa National Park } & 213,65 & \multirow{2}{*}{14253} \\
\hline & 26 & & $\begin{array}{l}\text { Hayedos de Picos de Europa - Canal } \\
\text { de A sotin }\end{array}$ & & 109,58 & \\
\hline & 27 & \multirow{2}{*}{ Spain } & Hayedos de Navarra - Lizardoia & Lizardoia Strict Reserve & 63,97 & \multirow{2}{*}{$\begin{array}{c}24494 \\
52\end{array}$} \\
\hline & 28 & & Hayedos de Navarra - Aztaparreta & A ztaparreta Strict R eserve & 171,06 & \\
\hline & 29 & \multirow[b]{2}{*}{ Spain } & Hayedos de A yllón - Tejera N egra & Hayedo Tejera N egra N atural Park & 255,52 & \multirow[b]{2}{*}{13880,86} \\
\hline & 30 & & $\begin{array}{l}\text { Hayedos de A yllón - M ontejo de la } \\
\text { Sierra }\end{array}$ & Sierra del Rincon Biosphere Reserve & 71,79 & \\
\hline & 31 & Slovenia & Snežnik-Ždrocle & Snežnik-Ždrocle Forest R eserve & 720,24 & 128,80 \\
\hline & 32 & Slovenia & Krokar & K rokar Forest Reserve & 74,50 & 47,90 \\
\hline & 33 & Romania & Strîmbu Băiuț & $\begin{array}{l}\text { Strictly protected area in Forest } \\
\text { M anagement Plans \& part of N2k } \\
\text { site Codrii Seculari de la Strâmbu- } \\
\text { Băiuț (ROSCI0285) }\end{array}$ & 598,14 & 713,09 \\
\hline & 34 & Romania & Izvoarele Nerei & $\begin{array}{l}\text { Semenic-Cheile Carasului National } \\
\text { Park }\end{array}$ & 4677,21 & 2494,83 \\
\hline & 35 & \multirow{2}{*}{ Romania } & Groșii Țibleșului - Preluci & \multirow{2}{*}{$\begin{array}{l}\text { Strictly protected areas in Forest } \\
M \text { anagement Plans }\end{array}$} & 135,82 & \multirow{2}{*}{563,57} \\
\hline & 36 & & Groșii Țibleșului - Izvorul Șurii & & 210,55 & \\
\hline
\end{tabular}




\begin{tabular}{|c|c|c|c|c|c|c|}
\hline & 37 & Romania & $\begin{array}{l}\text { Domogled-V alea Cernei - Ciucevele } \\
\text { Cernei }\end{array}$ & & 1104.27 & \\
\hline & 38 & Romania & $\begin{array}{l}\text { Domogled-V alea Cernei - Iauna } \\
\text { Craiovei }\end{array}$ & $\begin{array}{l}\text { Domogled-V alea Cernei National } \\
\text { Park }\end{array}$ & 3517,36 & 51461,28 \\
\hline & 39 & Romania & $\begin{array}{l}\text { Domogled-V alea Cernei - Coronini- } \\
\text { B edina }\end{array}$ & & 5110,63 & \\
\hline & 40 & Romania & Cozia - Lotrisor & & 1103,30 & \\
\hline & 41 & Romania & Cozia - M asivul Cozia & Cozia National Park & 2285,86 & 2408,83 \\
\hline & 42 & Romania & Codrul Secular Slătioara & $\begin{array}{l}\text { Codrul Secular Slătioara Forest } \\
\text { Reserve \& Natura } 2000 \text { site Rarău- } \\
\text { Giumalău (ROSCI0212) }\end{array}$ & 609,12 & 429,43 \\
\hline & 43 & Romania & Codrul secular Șinca & $\begin{array}{l}\text { Strictly protected areas in Forest } \\
M \text { anagement Plans }\end{array}$ & 338,24 & 445,76 \\
\hline & 44 & Romania & Cheile N erei-B eușnița & $\begin{array}{l}\text { Cheile N erei-B eusnita National Park } \\
\& \text { Natura } 2000 \text { sites Cheile N erei } \\
\text { (ROSCI0031) and B eusnita } \\
\text { (ROSPA 0020) }\end{array}$ & 4292,27 & 5959,87 \\
\hline & 45 & Italy & Sasso Fratino & $\begin{array}{l}\text { Sasso Fratino Strict Reserve in } \\
\text { Foreste Casentinesi N ational Park }\end{array}$ & 781,43 & 6936,64 \\
\hline & 46 & Italy & M onte R aschio & $\begin{array}{l}\text { M onte Raschio Strict Reserve in } \\
\text { Regional Natural Park of B racciano- } \\
\text { M artignano }\end{array}$ & 73,73 & 54,75 \\
\hline & 47 & Italy & M onte Cimino & $\begin{array}{l}\text { Natural M onument of the Lazio } \\
\text { Region }\end{array}$ & 57,54 & 87,96 \\
\hline & 48 & Italy & Foresta Umbra & $\begin{array}{l}\text { Foresta U mbra Strict Nature Reserve } \\
\text { in Gargano National Park }\end{array}$ & 182,23 & 1752,54 \\
\hline 胥 & 49 & Italy & Cozzo Ferriero & $\begin{array}{l}\text { Cozzo Ferriero Strict Reserve in } \\
\text { Pollino National Park }\end{array}$ & 95,74 & 482,61 \\
\hline$\frac{8}{x}$ & 50 & Italy & $\begin{array}{l}\text { A bruzzo, Lazio \& M olise - V al } \\
\text { Fondillo }\end{array}$ & & 325,03 & 700,95 \\
\hline & 51 & Italy & $\begin{array}{l}\text { A bruzzo, Lazio \& M olise - Coppo } \\
\text { del Principe }\end{array}$ & & 194,49 & 446,62 \\
\hline & 52 & Italy & $\begin{array}{l}\text { A bruzzo, Lazio \& M olise - Coppo } \\
\text { del M orto }\end{array}$ & $\begin{array}{l}\text { A bruzzo, Lazio \& M olise National } \\
\text { Park }\end{array}$ & 104,71 & 415,51 \\
\hline & 53 & Italy & $\begin{array}{l}\text { A bruzzo, Lazio \& M olise - Selva } \\
\text { M oricento }\end{array}$ & & 192,70 & \\
\hline & 54 & Italy & $\begin{array}{l}\text { A bruzzo, Lazio \& M olise - V alle } \\
\text { Cervara }\end{array}$ & & 119,70 & /51,61 \\
\hline & 55 & Croatia & $\begin{array}{l}\text { Paklenica National Park - } \\
\text { Oglavinovac-Javornik }\end{array}$ & & 790,74 & 395,35 \\
\hline & 56 & Croatia & $\begin{array}{l}\text { Paklenica National Park - Suva } \\
\text { draga-K limenta }\end{array}$ & Paklenica National Park & 1241,04 & 414,76 \\
\hline & 57 & Croatia & Hajdučki i Rožanski kukovi & $\begin{array}{l}\text { Strict Reserve Hajdučki and } \\
\text { Rožanski Kukovi within N orthern } \\
\text { V elebit N ational Park. }\end{array}$ & 1289,11 & 9869,25 \\
\hline & 58 & Bulgaria & Central Balkan - Sokolna R eserve & & 824,90 & 780,55 \\
\hline & 59 & Bulgaria & $\begin{array}{l}\text { Central B alkan - Peeshti skali } \\
\text { Reserve }\end{array}$ & & 1049,10 & 968,14 \\
\hline & 60 & Bulgaria & $\begin{array}{l}\text { Central B alkan - Severen Dzhendem } \\
\text { Reserve }\end{array}$ & & 926,37 & 1066,47 \\
\hline & 61 & Bulgaria & $\begin{array}{l}\text { Central B alkan - Dzhendema } \\
\text { Reserve }\end{array}$ & Strict Reserves within Central & 1774,12 & 2576,63 \\
\hline & 62 & Bulgaria & Central B alkan - Stara reka Reserve & & 591,20 & 1480,04 \\
\hline & 63 & Bulgaria & Central B alkan - Steneto Reserve & & 2466,10 & 1762,01 \\
\hline & 64 & Bulgaria & $\begin{array}{l}\text { Central B alkan - Kozya stena } \\
\text { Reserve }\end{array}$ & & 644,43 & 289,82 \\
\hline & 65 & Bulgaria & Central B alkan - Tsarichina R eserve & & 1485,81 & 1945,99 \\
\hline & 66 & Bulgaria & Central B alkan - B oatin Reserve & & 1226,88 & 851,22 \\
\hline
\end{tabular}


Beech Forests as World Heritage in aspect to the next extension of the Ancient and Primeval Beech Forests of the Carpathians and Other Regions of Europe World Heritage site

\begin{tabular}{|c|c|c|c|c|c|}
\hline 67 & B elgium & $\begin{array}{l}\text { Sonian Forest - Forest Reserve } \\
\text { "Joseph Zwaenepoel" }\end{array}$ & $\begin{array}{l}\text { Strict Forest Reserve "J oseph } \\
\text { Zwaenepoel" }\end{array}$ & 187,34 & \multirow{5}{*}{4650,86} \\
\hline 68 & Belgium & Sonian Forest - Grippensdelle A & \multirow{4}{*}{$\begin{array}{l}\text { Strict Forest Reserves within Sonian } \\
\text { forest Protected Landscape, } \\
\text { Natura2000 sites BE } 1000001 \text { and } \\
\text { BE } 2400008\end{array}$} & 24,11 & \\
\hline 69 & B elgium & Sonian Forest - Grippensdelle B & & 37,38 & \\
\hline 70 & B elgium & $\begin{array}{l}\text { Sonian Forest - Réserve forestière } \\
\text { du Ticton A }\end{array}$ & & 13,98 & \\
\hline 71 & B elgium & $\begin{array}{l}\text { Sonian Forest - R éserve forestière } \\
\text { du Ticton B }\end{array}$ & & 6,50 & \\
\hline 72 & A ustria & Kalkalpen - Wilder Graben & \multirow{4}{*}{$\begin{array}{l}\text { Kalkalpen N ational Park and } \\
\text { Natura2000 site AT3111000 }\end{array}$} & 1149,75 & \multirow{4}{*}{14197,24} \\
\hline 73 & A ustria & Kalkalpen - Urlach & & 264,82 & \\
\hline 74 & Austria & Kalkal pen - B odinggraben & & 890,89 & \\
\hline 75 & A ustria & Kalkal pen - Hintergebirge & & 2946,20 & \\
\hline 76 & A ustria & Dürrenstein & W ilderness A rea Dürrenstein & 1867,45 & 1545,05 \\
\hline 77 & Albania & Rrajca & Shebenik-J abllanica National Park & 2129,45 & 2569,75 \\
\hline 78 & Albania & Lumi i Gashit & Strict N ature Reserves Gashi River & 1261,52 & 8977,48 \\
\hline
\end{tabular}

Table 2: The components nominated as the $3^{\text {rd }}$ extension of the Ancient and Primeval Beech Forests of the Carpathians and Other Regions of Europe Natural World Heritage site (Kirchmeir \& Kovarovics, 2020)

\begin{tabular}{|c|c|c|c|c|c|}
\hline No. & State Party & Component part & Protected A rea & $\begin{array}{l}\text { Core zone } \\
\text { size (ha) }\end{array}$ & $\begin{array}{c}\text { Buffer } \\
\text { zone size } \\
\text { (ha) }\end{array}$ \\
\hline 1 & $\begin{array}{l}\text { Bosnia and } \\
\text { Herzegovina }\end{array}$ & Prašuma Janj & Prašuma J anj Strict $N$ ature R eserve & 295,04 & 380,74 \\
\hline 2 & $\begin{array}{l}\text { Czech } \\
\text { Republic }\end{array}$ & Jizera M ountains & $\begin{array}{l}\text { Jizerské hory National Nature } \\
\text { Reserve }\end{array}$ & 444,81 & 2330,40 \\
\hline 3 & France & Aigoual & Aigoual Biological Strict Reserve & 75.03 & 90.11 \\
\hline 4 & France & Chapitre & Chapitre Biological Strict Reserve & 371.30 & 41.65 \\
\hline 5 & France & Chizé Component 1 North-W est & \multirow{2}{*}{ Chizé B iological Strict Reserve } & 93.69 & \multirow{2}{*}{571.92} \\
\hline 6 & France & Chizé Component 2 South & & 62.43 & \\
\hline 7 & France & Fontainebleau & $\begin{array}{l}\text { Fontainebleau Biological Strict } \\
\text { Reserve }\end{array}$ & 248.48 & 152.20 \\
\hline 8 & France & Grand V entron & $\begin{array}{l}\text { Grand V entron National Nature } \\
\text { Reserve }\end{array}$ & 257.09 & 1397.58 \\
\hline 9 & France & M assane & $M$ assane $N$ ational N ature Reserve & 121.49 & 1551.33 \\
\hline 10 & France & Py-Pas de Rotja & $\begin{array}{l}\text { Py-Pas de R otja National Nature } \\
\text { Reserve }\end{array}$ & 246.03 & 4049.87 \\
\hline 11 & France & Sainte-B aume & $\begin{array}{l}\text { Sainte-B aume B iological Strict } \\
\text { Reserve }\end{array}$ & 128.63 & 215.11 \\
\hline 12 & France & Saint-Pé-de-Bigorre & $\begin{array}{l}\text { Saint-Pé-de-Bigorre Biological } \\
\text { Strict Reserve }\end{array}$ & 924.71 & 296.87 \\
\hline 13 & Italy & Cozzo Ferriero* & \multirow{2}{*}{ Pollino National Park } & 95.75 & \multirow{2}{*}{2851.83} \\
\hline 14 & Italy & Pollinello & & 477.94 & \\
\hline 15 & Italy & Falascone* & \multirow{2}{*}{ Foresta U mbra Strict N ature Reserve } & 254.30 & \multirow{2}{*}{3486.29} \\
\hline 16 & Italy & Pavari-Sfilzi & & 667.13 & \\
\hline 17 & Italy & V alle Infernale & $\begin{array}{l}\text { V alle Infernale Strict } N \text { ature } \\
\text { Reserve }\end{array}$ & 320.79 & 2191.36 \\
\hline 18 & M ontenegro & B iogradska Gora 1 & \multirow{2}{*}{ Biogradska Gora N ational Park } & 390.81 & \multirow{2}{*}{$3,632.82$} \\
\hline 19 & M ontenegro & B iogradska Gora 2 & & 1913.48 & \\
\hline 20 & $\begin{array}{l}\text { North } \\
\text { M acedonia }\end{array}$ & Dlaboka Reka & M avrovo National Park & 193.27 & 234.70 \\
\hline 21 & Poland & $\begin{array}{l}\text { B order Ridge and Gorna Solinka } \\
\text { valley }\end{array}$ & \multirow{4}{*}{ Bieszczady National Park } & 1506.05 & \multirow{4}{*}{24330.52} \\
\hline 22 & Poland & Polonina W etlinska and Smerek & & 1178.03 & \\
\hline 23 & Poland & Terebowiec stream valley & & 201.00 & \\
\hline 24 & Poland & Wolosatka stream valley & & 586.66 & \\
\hline
\end{tabular}




\begin{tabular}{|c|c|c|c|c|c|}
\hline 25 & Serbia & Fruška gora - Papratski do & \multirow{2}{*}{ Fruška gora National Park } & 65.36 & \multirow{2}{*}{847.86} \\
\hline 26 & Serbia & Fruška gora - Ravne & & 93.43 & \\
\hline 27 & Serbia & Kopaonik - Kozje stene & Kopaonik National Park & 451.47 & 959.89 \\
\hline 28 & Serbia & Tara - Zvezda & \multirow{2}{*}{ Tara National Park } & 1873.67 & \multirow{2}{*}{4091.99} \\
\hline 29 & Serbia & Tara - Rača & & 215.94 & \\
\hline 30 & Slovakia & Havešová Primeval Forest* & \multirow{4}{*}{ Poloniny National Park } & 167.88 & 6474,84 \\
\hline 31 & Slovakia & Rožok* & & 74.37 & 1138,89 \\
\hline 32 & Slovakia & Stužica - B ukovské V rchy* & & 1742.47 & 5694,84 \\
\hline 33 & Slovakia & U dava* & & 448.17 & 822,34 \\
\hline 34 & Slovakia & Kyjovský prales & \multirow{2}{*}{ V ihorlat Protected L andscape A rea } & 289.39 & 104.46 \\
\hline 35 & Slovakia & Vihorlat* & & 1559.41 & 847.54 \\
\hline 36 & Switzerland & Forêt de la B ettlachstock & $\begin{array}{l}\text { B ettlachstock-Hasenmatt } \mathrm{N} \text { atural } \\
\text { Forest Reserve }\end{array}$ & 195.43 & 1094.16 \\
\hline 37 & Switzerland & $\begin{array}{l}\text { Valli di Lodano, Busai and Soladino } \\
\text { Forest Reserves }\end{array}$ & Busai and Soladino Forest Reserves & 806.78 & 2330.74 \\
\hline
\end{tabular}

* boundary modification

Table 3: Forest reserves formerly included on Serbian Tentative list as extension components of the $3^{\text {rd }}$ extension of the Ancient and Primeval Beech Forests of the Carpathians and Other Regions of Europe Natural World Heritage site

\begin{tabular}{|c|c|c|c|}
\hline Name of the PA & $\begin{array}{l}\text { Protection } \\
\text { Date }\end{array}$ & B eech Forest A ssociations & Size \\
\hline Strict N ature Reserve Kukavica & 1980 & $\begin{array}{l}\text { Fagetum moesiacae serbicum (F agetum moesiaceae } \\
\text { montanum typicum, F agetum moesiae nudum - pauperum, } \\
\text { Luzulo-fagetum moesiacae) }\end{array}$ & 75.76 ha \\
\hline Strict $N$ ature R eserve Zeleničje & 1948 & $\begin{array}{l}\text { F agetum moesiacae montanum, Lauroceraso-F agetum } \\
\text { (with Prunus laurocerasus) }\end{array}$ & 41.70 ha \\
\hline $\begin{array}{l}\text { General Nature Reserve } \\
\text { V inatovača }\end{array}$ & 1957 & Fagetum moesiacae montanum & 37.43 ha \\
\hline $\begin{array}{l}\text { Strict N ature Reserve Golema } \\
\text { Reka }\end{array}$ & 1981 & Luzulo-fagetum moesiacae & 34.60 ha \\
\hline $\begin{array}{l}\text { Strict N ature R eserve V rh Željina } \\
\text { - Pločka čuka }\end{array}$ & 1985 & $\begin{array}{l}\text { F agetum moesiaceae montanum, Fagetum moesiacae } \\
\text { subalpnum }\end{array}$ & 20.00 ha \\
\hline Strict $N$ ature Reserve Felješana & 1903,1950 & Fagetum montanum asperulosum typicum & 15.28 ha \\
\hline Strict $N$ ature R eserve $B$ usovata & 1975 & Fagetum moesiacae montanum & 15.86 ha \\
\hline $\begin{array}{l}\text { General Nature Reserve } \\
\text { Danilova kosa }\end{array}$ & 1950 & Fagetum moesiacae montanum & 6.00 ha \\
\hline $\begin{array}{l}\text { Special N ature Reserve } M \text { ala } \\
\text { J asenova Glava }\end{array}$ & 1961 & $\begin{array}{l}\text { Taxo-F agetum moesiacae } \\
\text { (with Taxus baccata, Ruscus hypoglossum, Acer } \\
\text { heldreichii) }\end{array}$ & $6.30 \mathrm{ha}$ \\
\hline $\begin{array}{l}\text { Strict N ature Reserve Iznad } \\
\text { Tatalije }\end{array}$ & 1968 & Ilici-F agetum montanum (with Ilex aquifolium) & 0,80 ha \\
\hline Strict $N$ ature Reserve Zelenika & 1968 & Ilici-F agetum montanum (with Ilex aquifolium) & 0,45 ha \\
\hline
\end{tabular}


Beech Forests as World Heritage in aspect to the next extension of the Ancient and Primeval Beech Forests of the Carpathians and Other Regions of Europe World Heritage site

Table 4: Nominated components from Serbia in the $3^{\text {rd }}$ extension of the Ancient and Primeval Beech Forests of the Carpathians and Other Regions of Europe Natural World Heritage site

\begin{tabular}{|c|c|c|c|c|c|c|c|c|c|c|}
\hline $\begin{array}{l}\text { Component } \\
\text { type }\end{array}$ & $\begin{array}{l}\text { Component } \\
\text { part }\end{array}$ & $\begin{array}{c}\text { Protected } \\
\text { Area }\end{array}$ & $\begin{array}{l}\text { Level I } \\
\text { Protection } \\
\text { Regime } \\
\text { locality size } \\
\text { (ha) }\end{array}$ & $\begin{array}{c}\text { Core } \\
\text { zone size } \\
\text { (ha) }\end{array}$ & $\begin{array}{c}\text { Buffer } \\
\text { zone size } \\
\text { (ha) }\end{array}$ & $\begin{array}{c}\text { Ecologically } \\
\text { important } \\
\text { area of the } \\
\text { ecological } \\
\text { network of } \\
\text { the Republic } \\
\text { of Serbia }\end{array}$ & $\begin{array}{l}\text { Important } \\
\text { Bird Area }\end{array}$ & $\begin{array}{c}\text { Prime } \\
\text { Butterfly } \\
\text { Area }\end{array}$ & $\begin{array}{l}\text { Important } \\
\text { Plan Area }\end{array}$ & $\begin{array}{c}\text { Emerald } \\
\text { network site }\end{array}$ \\
\hline \multirow{2}{*}{$\begin{array}{l}\text { Component } \\
\text { cluster }\end{array}$} & $\begin{array}{l}\text { Fruška gora - } \\
\text { Papratski do }\end{array}$ & \multirow{2}{*}{$\begin{array}{l}\text { Fruška gora } \\
\text { National Park }\end{array}$} & 71.35 & 65.36 & \multirow{2}{*}{847.86} & \multirow{2}{*}{$\begin{array}{l}\text { 14. Fruška } \\
\text { gora i } \\
\text { Koviljski } \\
\text { rit }\end{array}$} & \multirow{2}{*}{$\begin{array}{c}\text { Fruška } \\
\text { gora } \\
\text { RS019IBA }\end{array}$} & \multirow{2}{*}{$\begin{array}{c}\text { Fruška gora } \\
07\end{array}$} & \multirow{2}{*}{$\begin{array}{c}\text { Fruška } \\
\text { gora i } \\
\text { Koviljsko- } \\
\text { petrovaradi- } \\
\text { nski rit }\end{array}$} & \multirow{2}{*}{$\begin{array}{l}\text { Fruška gora } \\
\text { RS0000007 }\end{array}$} \\
\hline & $\begin{array}{l}\text { Fruška gora - } \\
\text { Ravne }\end{array}$ & & 95.69 & 93.43 & & & & & & \\
\hline $\begin{array}{c}\text { Single } \\
\text { component }\end{array}$ & $\begin{array}{l}\text { Kopaonik - } \\
\text { Kozje stene }\end{array}$ & $\begin{array}{l}\text { Kopaonik } \\
\text { National Park }\end{array}$ & 485.24 & 451.47 & 959.89 & $\begin{array}{c}75 . \\
\text { Kopaonik }\end{array}$ & $\begin{array}{r}\text { Kopaonik } \\
\text { RS032IBA }\end{array}$ & $\begin{array}{c}\text { Kopaonik } \\
16\end{array}$ & Kopaonik & $\begin{array}{c}\text { Kopaonik } \\
\text { RS0000002 }\end{array}$ \\
\hline \multirow{2}{*}{$\begin{array}{l}\text { Component } \\
\text { cluster }\end{array}$} & Tara - Zvezda & \multirow{2}{*}{$\begin{array}{l}\text { Tara National } \\
\text { Park }\end{array}$} & 2030.18 & 1873.67 & \multirow{2}{*}{4091.99} & \multirow{2}{*}{ 61. Tara } & \multirow{2}{*}{$\begin{array}{c}\text { Tara } \\
\text { RS026IBA }\end{array}$} & \multirow{2}{*}{ Tara 25} & \multirow{2}{*}{ Tara } & \multirow{2}{*}{$\begin{array}{c}\text { Tara } \\
\text { RS0000009 }\end{array}$} \\
\hline & Tara - Rača & & 301.80 & 215.94 & & & & & & \\
\hline
\end{tabular}

Figure 1: The 12 Beech Forest Regions in Europe, as defined by the 2012 Screening Study (Ibisch, 2014)

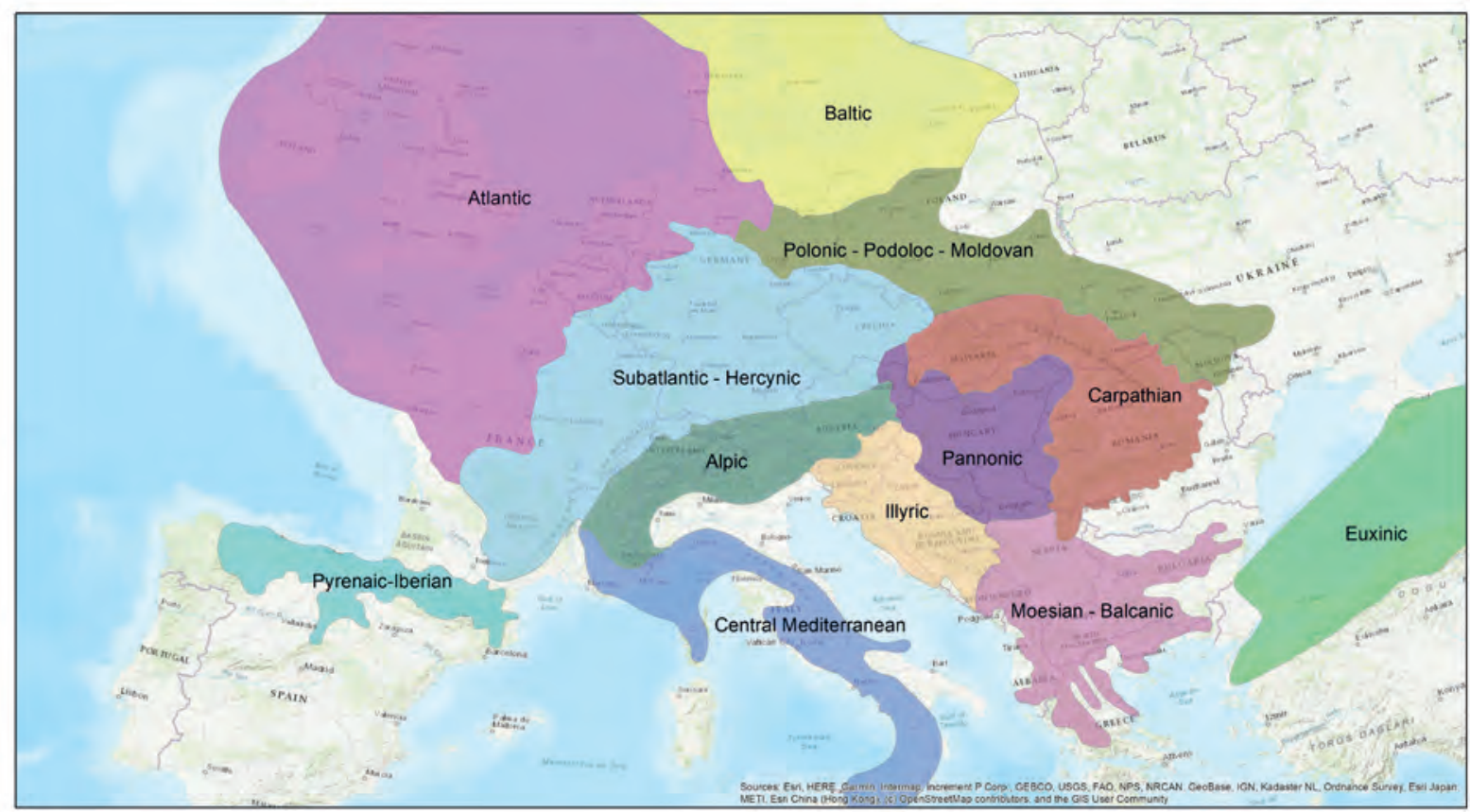

\begin{tabular}{|c|c|c|c|c|c|c|}
\hline \multicolumn{3}{|c|}{ Beech Forest Regions (BFR) } & \multirow{4}{*}{$\stackrel{N}{\Lambda}$} & \multirow{2}{*}{$\begin{array}{l}\text { Alpic } \\
\text { Atlantic }\end{array}$} & \multirow{2}{*}{$\begin{array}{l}\text { Central Mediterranean } \\
\text { Euxinic }\end{array}$} & \multirow{2}{*}{$\begin{array}{l}\text { Pannonic } \\
\text { Polonic - Podoloc - Moldovan }\end{array}$} \\
\hline \multirow{2}{*}{\multicolumn{3}{|c|}{$\begin{array}{l}\text { Background: ESRI Topografic Baselayer } \\
\text { Projection: Europe Albers Equal Area Conic }\end{array}$}} & & & & \\
\hline & & & & Baltic & Illyric & Pyrenaic-Iberian \\
\hline$\stackrel{0}{L}$ & $500 \mathrm{Km}$ & Scale: $1: 10000000$ & & Carpathian & Moesian - Balkanic & Subatlantic - Hercynic \\
\hline
\end{tabular}


Figure 2: Spatial distribution of the inscribed components and the nominated components as the $3^{\text {rd }}$ extension of the Ancient and Primeval Beech Forests of the Carpathians and Other Regions of Europe Natural World Heritage site (Kirchmeir \& Kovarovics, 2020)
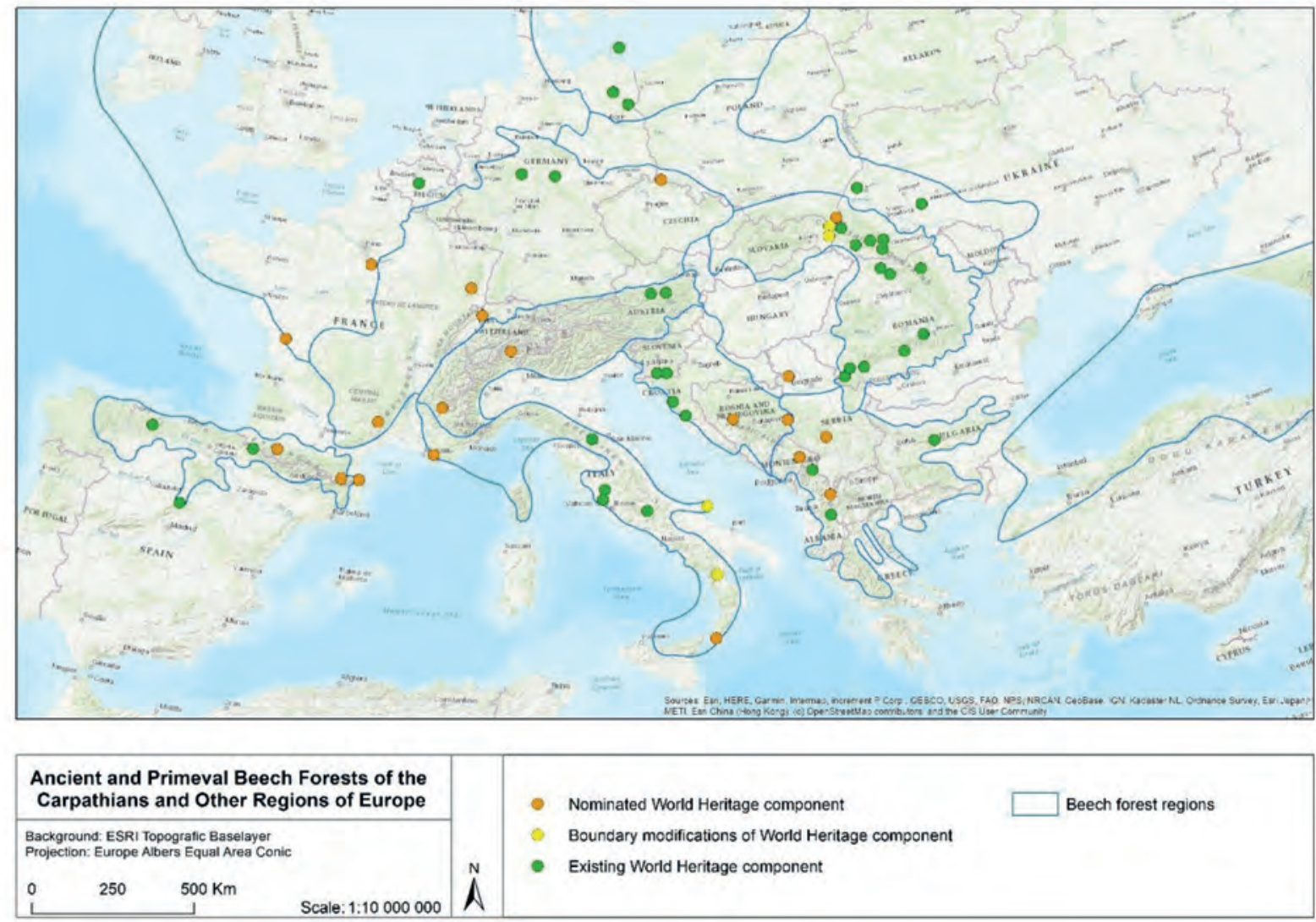

\section{REFERENCES}

Agnoletti, M.\& Dargavel, J. \& Johann, E. (2009): History of forestry. In: V. Squire (ed.). The Role of Food, Agriculture, Forestry and Fisheries in Human $\mathrm{Nu}-$ trition - Vol. II. Eolss Publishers, Oxford pp. 1-28

Anonymous (2006): World Heritage nomination dossier: Primeval Beech Forests of the Carpathians, 73p. http://whc.unesco.org/en/list/1133/documents Badman, T. \& Bomhard, B. \& Fincke, A. \& Langley, J. \& Rosabal, P. \& Sheppard, D. (2008): Outstanding universal value: Standards for natural world heritage. Gland, Switzerland: IUCN. 52pp.

Barbati, A. \& Salvati, R. \& Ferrari, B. \& Di Santo, D. \& Quatrini, A. \& Portoghesi, L. \& Travaglini, D. \& Iovino, F. \& Nocentini, S. (2012): Assessing and promoting oldgrowthness of forest stands: lessons from research in Italy. Plant Biosystems, 146 (1): 167-174.

Bengtsson, J. \& Nilsson, S. G. \& Franc, A. \& Menozzi, P. (2000): Biodiversity, disturbances, ecosystem function and management of European forests. Forest Ecology and Management 132: 39-50 pp.
Britz, H. \& Dieckmann, O. \& Engels, B. \& Frede, A. \& Geisel, T. \& Großmann, M. \& Kaiser, K. \& Knapp, H. D. \& Luthardt, M.E. \& Seuring, J. (eds.) (2009): Nomination of the "Ancient Beech Forests of Germany" as Extension to the World Natural Heritage "Primeval Beech Forests of the Carpathians" (1133) - Nomination Dossier to the UNESCO for the Inscription on the World Heritage List, 161p. https:// whc.unesco.org/document/155684

Britz, H. (eds.) (2015): Beech Forests - UNESCO World Natural Heritage - Protecting a unique ecosystem. Federal Ministry for the Environment, Nature Conservation, Building and Nuclear Safety (BMUB) Berlin, Germany. 39pp.

Brunet, J. \& Fritz, Ö. \& Richnau, G. (2010): Biodiversity in European beech forests - a review with recommendations for sustainable forest management. Ecological Bulletins 53. 77-94.

Christensen, M. \& Hahn, K. \& Mountford, E.P. \& Odor, P. \& Standovar, T. \& Rozenbergar, D. \& Diaci, J. \& Wijdeven, S. \& Meyer, P. \& Winter, S. \& Vrska, T. 
(2005): Dead wood in European beech (Fagus sylvatica) forest reserves. Forest Ecology and Management 210: 267-282 pp.

Commarmot, B. \& Brändli, U.B. \& Hamor, F. \& Lavnyy, V. (eds) (2013): Inventory of the Largest Primeval Beech Forest in Europe - a Swiss-Ukrainian Scientific Adventure. Birmensdorf, Swiss Federal Research Institute WSL; L'viv, Ukrainian National Forestry University; Rakhiv, Carpathian Biosphere Reserve. 69 pp.

Diaci, J. (eds.) (1999): Virgin forests and forest reserves in Central and East European countries: history, present status and future development. Proceedings of the invited lecturers' reports presented at the COST E4 management committee and working groups meeting in Ljubljana, Slovenia, 25-28th April 1998. Department of Forestry and Renewable Forest Resources - Biotechnical Faculty in Ljubljana.

EUROPARC-España (2017): Old-growth forests: characteristics and conservation value. Ed. Fundación Fernando González Bernaldez, Madrid.

Glatthorn, J. \& Feldmann, E. \& Tabaku, V. \& Leuschner, C. \& Meyer, P. (2018): Classifying development stages of primeval European beech forests: is clustering a useful tool? BMC Ecology 18, Article No. 47

Hahn, K., \& Fanta, J. (2001): Contemporary beech forest management in Europe: Working Report 1. University of Copenhagen

Harmon, M. \& Franklin, J. \& Swanson, F. \& Sollins, P. \& Gregory, S. \& Lattin, J. \& Anderson, N. \& Cline, S. \& Aumen, N. \& Sedell, J.R. \& Lienkaempeer, G. \& Cromack, K. (1986): Ecology of Coarse Woody Debris in Temperate Ecosystems. Advances in Ecological Research 15(C) 10.1016/S0065-2504(03)340024.

Ibisch, P. (2014): European World Heritage Beech Forests. Research and Development project of German Federal Agency for Nature Conservation - Final Project Report. Hochschule für nachhaltige Entwicklung Eberswalde (FH). Eberswalde, Germany.

IUCN (2006): The world heritage list: Guidance and future priorities for identifying natural heritage of potential outstanding universal value, IUCNRep-2006-004, 28 p.

IUCN (2007): World Heritage Nomination - IUCN Technical evaluation, Primeval Beech Forests of the Carpathians (Slovakia, Ukraine). Gland, Switzerland. http://whc.unesco.org/document/151832

IUCN (2011): World Heritage Nomination - IUCN Technical evaluation, Ancient Beech Forests of Germany (Extension of Primeval Beech Forests of the Carpathians, Slovakia and Ukraine). Gland, Switzerland. https://whc.unesco.org/document/151834
IUCN (2017): World Heritage Nomination - IUCN Technical evaluation, Primeval Beech Forests of the Carpathians and Other Regions of Europe (Albania, Austria, Belgium, Bulgaria, Croatia, Italy, Romania, Slovenia, Spain, Ukraine). Gland, Switzerland. http://whc.unesco.org/document/159695

Karadžić, B. (2018): Beech forests (order Fagetalia sylvaticae Pawlowski 1928) in Serbia. Botanica Serbica 42 (1): 91-107.

Kirchmeir, H. \& Kovarovics, A. (eds.) (2016): Nomination Dossier „Primeval Beech Forests of the Carpathians and Other Regions of Europe" as extension to the existing Natural World Heritage Site "Primeval Beech Forests of the Carpathians and the Ancient Beech Forests of Germany" (1133bis). Klagenfurt, 409 p. http://whc.unesco.org/document/151834

Kirchmeir, H. \& Kovarovics, A. (eds.) (2016a): Supplementary Information on the Nomination "Primeval Beech Forests of the Carpathians and Other Regions of Europe" as extension to the existing Natural World Heritage Site "Primeval Beech Forests of the Carpathians and the Ancient Beech Forests of Germany" (1133bis). Klagenfurt, 41 p.

Kirchmeir, H. \& Kovarovics, A. (eds.) 2020: Nomination Dossier 'Ancient and Primeval Beech Forests of the Carpathians and Other Regions of Europe' as extension to the existing Natural World Heritage Site (1133ter). Klagenfurt, 357p

Knapp, H.D. \& Fichtner, A. (eds.) (2011): Beech Forests - Joint Natural Heritage of Europe BfN-Skripten 327. $197 \mathrm{pp}$.

Kruse, A. \& Paulowitz, B. \& Kruckenberg, H. (2009): Requirements for the management of protected areas according to the UNESCO world heritage convention and IUCN categories, Tájökológiai Lapok 7 (1): 209-227.

Lonsdale, D. \& Pautasso, M. \& Holdenrieder, O. (2008): Wood-decaying fungi in the forest: conservation needs and management options. - European Journal of Forest Research 127: 1-22.

Magri, D. \& Vendramin, G. G. \& Comps, B. \& Dupanloup, I. \& Geburek, T. \& Gömöry, D. \& Latałowa, M. \& Litt, T. \& Paule, L. \& Roure, J. M. \& Tantau, I. \& Van Der Knaap, W. O. \& Petit, R. J. \& De Beaulieu, J. (2006): A new scenario for the Quaternary history of European beech populations: palaeobotanical evidence and genetic consequences. New Phytologist, 171: 199-221. doi:10.1111/j.14698137.2006.01740.x

Matović, B. \& Koprivica, M. \& Kisin, B. \& Stojanović, D. \& Kneginjić, I. \& Stjepanović, S. (2019): Comparison of Stand Structure in Managed and Virgin 
European Beech Forests in Serbia. Šumarski list, 1-2: 47-57.

Milovanović, B. (2019): Plan upravljanja Nacionalnog parka Kopaonik od 2019. do 2028. [Kopaonik National Park management plan for the period 20192028] JP NP Kopaonik, Kopaonik

Rugani, T. \& Diaci, J. \& Hladnik, D. (2013): Gap Dynamics and Structure of Two Old-Growth Beech Forest Remnants in Slovenia. PLoS ONE 8(1): e52641. doi:10.1371/journal.pone.0052641

Sabatini, F. \& Burrascano, S. \& Keeton, W. \& Levers, C. \& Lindner, M. \& Pötzschner, F. \& Verkerk, H. \& Bauhus, J. \& Buchwald, E. \& Chaskovsky, O. \& Debaive, N. \& Horvath, F. \& Garbarino, M. \& Grigoriadis, N. \& Lombardi, F. \& Duarte, I. \& Meyer, P. \& Midteng, R. \& Mikac, S. \& Kuemmerle, T. (2018): Where are Europe's last primary forests? Diversity and Distributions 24:1426-1439. 10.1111/ ddi.12778.

UNESCO, 2017: Operational Guidelines for the Implementation of the World Heritage Convention. Revised document adopted by WH Committee Decision: 41 COM 11, https://whc.unesco.org/en/ guidelines/

Vandekerkhove, K. \& De Keersmaeker, L. \& Menke, N. \& Meyer, P. \& Verschelde, P. (2009): When nature takes over from man: Dead wood accumulation in previously managed oak and beech woodlands in North-western and Central Europe. Forest Ecology and Management 258: 425-435 pp. 10.1016/j. foreco.2009.01.055.

Vološčuk, I. (2013a): From Research of the Carpathian Beech Virgin Forests to the World heritage. 5th Symposium for Research in Protected Areas, 10 to 12 June 2013, Mittersill - Conference Volume, 789 -794 .

Vološčuk, I. (2013b): Uniqueness, Authenticity and Integrity of the Primeval Beech Forests of the Carpathians as World Heritage Sites. Thaiszia - J. Bot. 23 (1): 23-30.

Vološčuk, I. (2014): Joint Slovak-Ukraine-Germany Beech Ecosystems as the World Natural Heritage. Ekologia. 33. 10.2478/eko-2014-0027.

Vološčuk, I. \& Pichler, V. \& Pichlerova, M. (2013): The Primeval Beech Forests of the Carpathians and Ancient Beech Forests of Germany: Joint natural Heritage of Europe. Folia Oecologica 40, No. 2: 295-303.

WHC - World Heritage Committee (2004): Decision 28 COM 14B.2. Primeval Forests of Slovakia (Slovakia) - request by the State Party not to examine submitted nomination. Suzhou, China. https://whc. unesco.org/archive/2004/whc04-28com-26e.pdf

WHC - World Heritage Committee (2007): Decision 31 COM 8B.16. Primeval Beech Forests of the Car- pathians (Slovakia and Ukraine). Christchurch, New Zealand https://whc.unesco.org/en/decisions/1314

WHC - World Heritage Committee (2011): Decision 35 COM 8B.13. Primeval Beech Forests of the Carpathians and the Ancient Beech Forests of Germany (Slovakia, Ukraine and Germany). Paris, UNESCO Headquarters https://whc.unesco.org/en/decisions $/ 4284$

WHC - World Heritage Committee (2017): Decision 41COM 8B.7. Ancient and Primeval Beech Forests of the Carpathians and Other Regions of Europe (Albania, Austria, Belgium, Bulgaria, Croatia, Italy, Germany, Romania, Slovenia, Slovakia, Spain, Ukraine). Krakow, Poland. http://whc.unesco.org/ en/decisions/6879

Willim, K. \& Stiers, M. \& Annighöfer, P. \& Ammer, C. \& Ehbrecht, M. \& Kabal, M. \& Stillhard, J. \& Seidel, D. (2019): Assessing Understory Complexity in Beech-dominated Forests in Central EuropeFrom Managed to Primary Forests. Sensors 19, 1684. doi:10.3390/s19071684

Wirth, C. \& Messier, C. \& Bergeron, Y. \& Frank, D. \& Fankhanel, A. (2009): Old-Growth Forest Definitions: a Pragmatic View. In: Wirth et al. (eds.) Old Growth Forests, Ecological Studies 207, 11-33. Springer Verlag Berlin Heidelberg

Winter, S. (2012): Forest naturalness assessment as a component of biodiversity monitoring and conservation management, Forestry 85(2) 293-304.

\section{Legislation:}

Law on Nature Protection (Official Gazette of RS, No. 36/09; 88/2010; 91/2010, 14/2016 and 95/2018)

Decree on Protection Regimes (Official Gazette of RS, No. 31/2012)

Decree on Ecological Network (Official Gazette of RS, No. 102/2010)

Law on National Parks ("Official Gazette of RS", No. 84/2015)

\section{Links:}

https://whc.unesco.org/

https://whc.unesco.org/en/list/

https://whc.unesco.org/en/committee/

https://whc.unesco.org/en/tentativelists/

https://whc.unesco.org/en/faq/9/

https://whc.unesco.org/en/statesparties/rs

https://www.skijanje.rs/istorija/istorija-skijanjau-srbiji/pocetci-skijanja-na-kopaoniku/

(All accessed on 19.01.2020.) 